\title{
Smart Grid Implementation in Electricity Distribution of Elektroprivreda B\&H - Dequirements and Objectives
}

\author{
E. Bećirović, M. Musić, N. Hasanspahić, S. Avdaković
}

\begin{abstract}
In terms of power sector restructuring and electricity market opening there have been significant changes in the functioning of activities at the level of Public Enterprise Elektroprivreda BiH d.d - Sarajevo (EPBiH). Distribution activity in an open electricity market is not a market activity, but the regulated activity, and although does not participate directly in the electricity market, its action must allow unhindered development and functioning of the market in which suppliers competes. The introduction of the smart grid concept in electricity distribution activity is a particularly challenging area of research due to the actuality and importance. The paper presents the elements of the business framework of EPBiH in terms of application of modern technologies in the area of smart grid and the changes that inevitably occur during transition process of energy sector in general.
\end{abstract}

Index Terms - smart grid, regulatory framework, electricity market, distribution activity

\section{INTRODUCTION}

$\mathrm{I}_{\mathrm{i}}$ $\mathrm{N}$ terms of restructuring the power sector, in general, there is no unique model for the transition from vertical integrated company that performs all activities (generation, transmission, distribution and supply) to separate business activities and open market. In early 90-ies of the last century, countries in transition started with the implementation of comprehensive economic, institutional and political reform, and energy reform are only part of much broader structural adjustment transition countries standards of market economies. The dynamics of power sector restructuring in the SEE countries is significantly affected by the socio-economic circumstances: the transition from the socialist system with a "planned

E. Bećirović is with the Department for Development, EPC Elektroprivreda BiH d.d. Sarajevo, 71000 Sarajevo, Bosnia and Herzegovina (e-mail: e.becirovic@elektroprivreda.ba).

M. Musić, is with the Department for Development, EPC Elektroprivreda $\mathrm{BiH}$ d.d. Sarajevo, 71000 Sarajevo, Bosnia and Herzegovina (e-mail: m.music@elektroprivreda.ba).

N. Hasanspahić is with the Department for Development, EPC Elektroprivreda BiH d.d. Sarajevo, 71000 Sarajevo, Bosnia and Herzegovina (e-mail: n.hasanspahic@elektroprivreda.ba).

S. Avdaković is with the Department for Development, EPC Elektroprivreda BiH d.d. Sarajevo, 71000 Sarajevo, Bosnia and Herzegovina (e-mail: s.avdakovic@elektroprivreda.ba) economy" of the democratic system and an economy based on market principles, followed by a lack of domestic and foreign investments entering the country in the region. The main objectives of the restructuring in this area are: improve efficiency (technical and financial) of power system, and reduce the burden of public finance through the elimination of subsidies for the production and transmission of electricity and the privatization of companies in the sector. Along with the requirements for the power sector restructuring, distribution activity needs to meet the requirements and implementation of modern technologies and other technical challenges.

\section{ELECTRICITY DISTRIBUTION ACTIVITY IN MARKET ENVIRONMENT}

\section{A. Unbundling of electricity business activities}

Unbundling of system activities (transmission and distribution) and market activities (generation and supply) is essential for the transparency business of electric power companies according to the EU Directives governing the internal electricity markets [1]. Unbundling implies financial, legal and functional unbundling of traditional vertically organized companies and creation of different stakeholders in electricity markets [2]. After the financial and functional unbundling, the ultimate objective is the legal unbundling of activities within the utilities. Within distribution activity, as it is observed from the current position, the objectives of liberalization are the fact that the supply activity is set aside as a separate market activity, and that the distribution system operator obtains the status of the regulated entity. Overview of interactions among electricity market stakeholders are given on Figure 1.

\section{B. Unbundling of electricity business activities}

Having signed the Electricity Policy Statement in 2000, having adopted the entity Laws on electricity, Law on transmission, regulator and system operator of electricity in $\mathrm{B} \& \mathrm{H}$ in 2002, Law on establishment of the company for transmission for electricity in B\&H and Law on establishment of Independent System Operator (ISO) for the transmission system of $\mathrm{B} \& \mathrm{H}$ in 2004, the reform of the electric power sector in B\&H was initiated. This process has been additionally reinforced by signing of the Treaty on establishment of the Energy Community in the region of the 
SEE in 2005. The State Regulatory Commission for electricity (SERC) made Decision on the volume, terms and conditions and timetable of the market opening in B\&H (June 2006. and 2009.) based on the Law on transmission, regulator and system operator of electricity in B\&H [6].

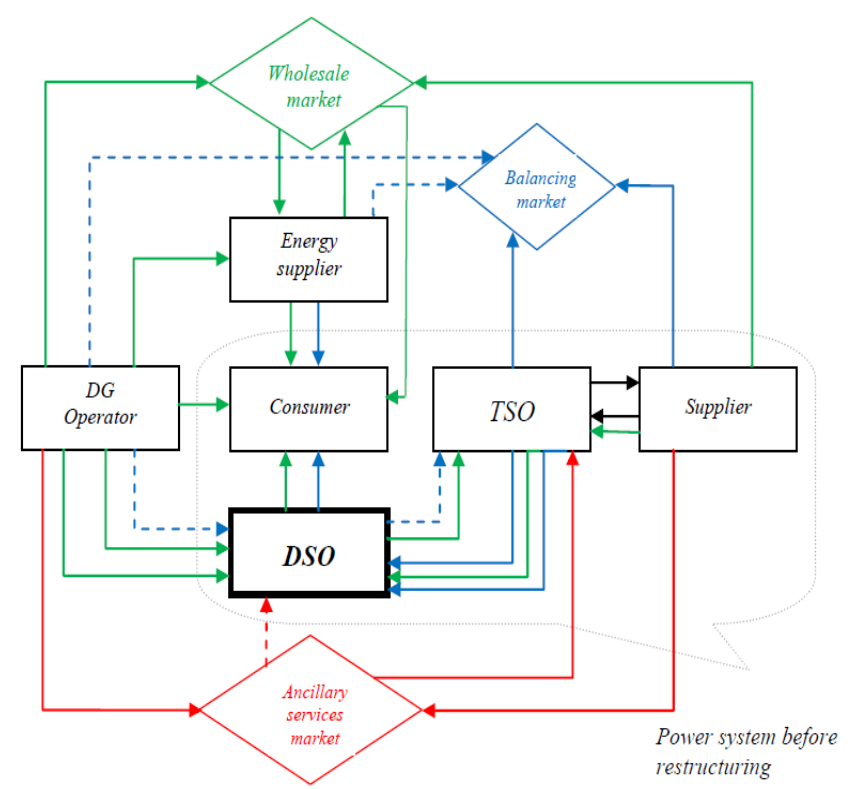

Fig. 1. Interactions among electricity market stakeholder [3], [4], [5]

\section{SMART GRID CONCEPT}

According to the above noted legislation, today Public Enterprise Elektroprivreda $\mathrm{BiH}(\mathrm{EPBiH})$ is conducting licensed activities of generation, production, distribution and supply of electricity, trading, representation and mediation in the domestic electricity market, as well as other activities determined by the applicable documents. Current market activity in B\&H is virtually non-existent even the legislation at the level of the power sector is judged as adequate by more competent independent subjects. This refers mainly to the definition of the relationship between distribution and supply activities. In accordance with the practice of some countries, some problems between the distribution system operators and suppliers are expected i.e. the exchange of data, the communications, the vague responsibilities for individual business processes, as well as the appearance of redundant processes. So, well-known processes, reliable IT support and relatively clear responsibility and accountability for their implementation are becoming the new "generator of business risk." The division of responsibilities between business processes and the functional unbundling of activities in accordance with applicable laws and regulations are some of the next targets in EPBiH. By the Law Establishing the Company for the Transmission of Electric Power in B\&H (2004.) one joint company for transmission power system (Elektroprijenos/Elektroprenos $\mathrm{BiH}$ ) is formed officially in 2006. The entity regulatory commissions have made decision on adoption of the Rule book on eligible customer in which the phase dynamics of electricity market opening and eligible customer status are treated [6].

\section{CURRENT STATUS OF IMPLEMENATION OF SMART GRID CONCEPT}

\section{A. Advance metering system}

One of the business objectives of $\mathrm{EPBiH}$, as determined and defined in appropriate organizational documents, is the implementation of advance metering system as an essential prerequisite for the continued implementation of the smart grid concept. Active engagement in the development of infrastructure for advance metering system (AMR/AMM system) began in late 2009 in $\mathrm{EPBiH}$. The previous implementation of AMR/AMM system implied a multi-phase process, in accordance with business strategy and company organization.

A brief overview of current status of AMR/AMM system implemented in distribution network of $\mathrm{EPBiH}$ is given in Table 1.

TABLE I

OVERVIEW OF AMR/AMM SYSTEM IMPLEMENTATION IN DISTRIBUTION NETWORK OF EPBIH

\begin{tabular}{lrr}
\hline \hline $\begin{array}{l}\text { Distribution branch } \\
\text { office }\end{array}$ & \multicolumn{1}{l}{$\begin{array}{l}\text { Number of installed } \\
\text { electronic meters }\end{array}$} & $\begin{array}{l}\text { Number of meters in } \\
\text { AMR/AMM system }\end{array}$ \\
\hline ED Bihać & 5.757 & 3.427 \\
ED Mostar & 3.028 & 2.281 \\
ED Sarajevo & 12.057 & 7.213 \\
ED Tuzla & 9.597 & 3.099 \\
ED Zenica & 12.152 & 4.217 \\
Total EPBiH & 42.591 & 20.237
\end{tabular}

Ongoing activity in EPBiH is implementation of Meter Data Management system (MDM) which is a module of total IT system of $\mathrm{EPBiH}$, which will be designed to collect, store, analyze and interpret data from AMR/AMM smart meters independently of type of activity (generation or distribution) [9] .

\section{B. Countermeasures for reduction of losses}

Due to the current lack of proper infrastructure of metering in TS $10(20) / 0,4 \mathrm{kV}$, it is not possible to define the adequate allocation of electricity losses on voltage levels. According to available metering data and by using certain approximations and expert experience this allocation is estimated for certain purposes. Also, in accordance with obligations defined in „General Conditions for Electricity Supply“ [10], EPBiH is constantly warning the customers about the need for conduction of reactive power compensation corresponding to average power factor $(\cos \phi=0.95)$. With adoption of new technical guidelines for substations TS $10(20) / 0.4 \mathrm{kV}$ with anticipated installation of reactive power compensation devices, EPBiH started with systematic (planned) reactive power compensation in own electricity distribution network

\section{Distributed generation requirements}

Total share of distributed generation, mainly small hydro power plants, is continually increasing in distribution network. Since this process takes place in parallel with the process of adjusting the distribution system operator, as well as other participants in the electricity sector to work in a market 
environment, it is necessary to take into account the requirements for normal distribution network operation. Distribution system operator analyses the impact of distributed generation to the grid, which can be positive and negative in general. Certain incentives for distributed generation through appropriate legal and regulatory requirements, and the obligation to allow equitable access on distribution network create the business environment in which the distribution activity is faced with the opposite requirements when the results of performed energy analysis show a negative impact of DG on distribution network operation. An example of such situation is the case with an increased level of losses in distribution networks with connected distributed generators (the influence of small hydro power plants in Uskoplje and Fojnica electricity distribution network areas), due to dislocation of DG and "centre of consumption“ in distribution network. Also, it is important to emphasize recent significant increase in interest in the construction and connection of photovoltaic power plants [9].

TABLE II

OVERVIEW OF DG STATUS IN EPBIH - NUMBER OF ISSUED OR REQUESTED PERMISSIONS FOR DG CONNECTION (JANUARY 2013.)

\begin{tabular}{lllll}
\hline \hline Type of DG & $\begin{array}{l}\text { Number of } \\
\text { connected } \\
\text { DGs }\end{array}$ & $\begin{array}{l}\text { Permitted } \\
\text { installed } \\
\text { power of } \\
\text { connected } \\
\text { DG [MW] }\end{array}$ & $\begin{array}{l}\text { Number of } \\
\text { requests for } \\
\text { DG } \\
\text { connection } \\
\text { (in process) }\end{array}$ & $\begin{array}{l}\text { Planned installed } \\
\text { power of DG as } \\
\text { requested[MW] }\end{array}$ \\
\hline $\begin{array}{l}\text { Small hydro } \\
\text { power plant }\end{array}$ & 38 & 42,00 & 4 & 4,6 \\
$\begin{array}{l}\text { Photovoltaic } \\
\text { power plant }\end{array}$ & 2 & 0,123 & 34 & 9,8 \\
\hline
\end{tabular}

\section{Increase of reliability of electricity supply indices}

In accordance to business plans of $\mathrm{EPBiH}$, modern SCADA/DMS control centres are planned to be implemented. With other power utilities EPBiH participated in the creation of feasibility study for the introduction of SCADA/DMS system in power distribution system [11]. But full implementation of SCADA/DMS system has not yet begun in $\mathrm{EPBiH}$, and the level of automation of the distribution network is quite low, but $\mathrm{EPBiH}$ is continuing investments in distribution network automation. During some previous investment programs individual projects of distribution network automation were implemented (i.e. installation of remotely operated circuit breakers and disconnectors and fault locators).

Continual monitoring and calculation of reliability of electricity supply indices (SAIFI: The number of supply interruptions per customer and SAIDI: duration of supply interruptions in minutes per customer) is a process that enables the benchmarking and gives a more detailed insight in distribution network performance of EPBiH). In Figure 2, an increasing trend in reliability of electricity supply is visible. Significant differences in the values of the reliability indices can be noticed in ED Sarajevo due to the network structure and current level of distribution network automation.
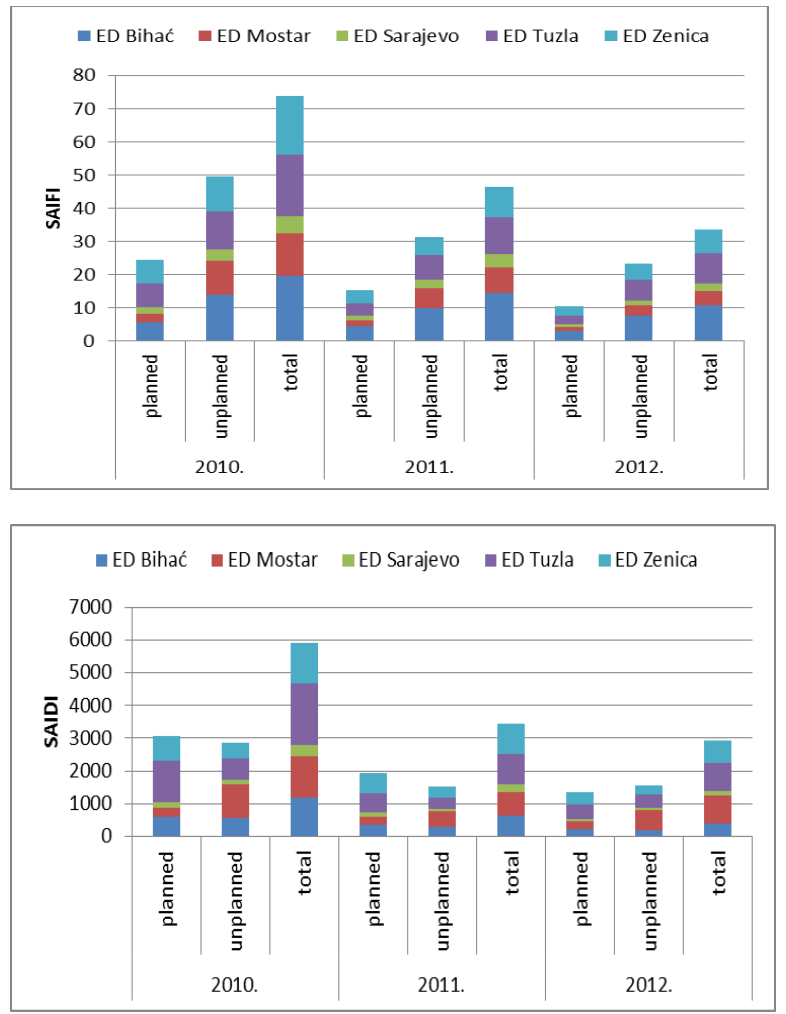

Fig. 2. Reliability of electricity supply indices SAIFI and SAIDI 2010. - 2012.

\section{E. Electricity demand management and active participation of consumers}

Currently, power utilities in B\&H do not have a detailed insight into the structure of electricity consumption, due to the lack of proper infrastructure of metering. The result of this situation is an estimation of load profiles, and also the estimation of total cost of the system during determination process of electricity tariffs accordingly. There is an ongoing project for load profile analysis that is performed in cooperation with the USAID-REAP, regulatory agencies and other power utilities in $\mathrm{B} \& \mathrm{H}$ [9]. According to project documentation, defined goals (direct or indirect) of this project are:

- Determination of adequate consumption groups

- Definition of characteristic consumption profiles for selected categories

- Scheduling of costs in accordance with consumption profiles

- Determination of the maximum consumption and simultaneity

- Effective electricity demand management

- Application to other areas.

\section{F. Other activities and current business framework requirements}

During the last few years at EPBiH some research were performed with the aim of further education and training of employees with specific requirements for the implementation of smart grid. Some activities were initiated in the selection of pilot projects in order to establish certain functionalities of 
smart networks. Among other things, a pilot project for the installation of the first electric vehicle charging station in Bosnia and Herzegovina is started. Also, three pilot projects for testing of equipment and systems for power quality monitoring are realized, in order to prepare for the implementation of this system as a preparation for response to the demands of electricity supply in accordance with EN 50160 from 2015, since this is requested in [10]. Full deployment of smart grid requires full support of legislative and regulatory bodies, as well as the participation of all other electricity sector stakeholders: distribution system operators, regulatory agencies, final customers of electricity, and distributed generation connected to distribution network

\section{CONCLUSION}

In terms of power sector restructuring, the distribution activity or distribution system operator functionality becomes more complex and demanding. In such new conditions, electricity distribution business must be fully customized to modern statutory provisions and regulations that are subject to frequent changes. Additionally, the distribution activity must respond to the technical challenges associated with the integration of DG and electric vehicles, the establishment of the system for collecting, processing, storing, and sharing information with all participants in the market to allow the normal functioning of electricity markets etc. Smart grid concept is the future challenge that will require further implementation of modern information technology in the area of distribution network operation, and also further linking of IT and business process-level activities.

In accordance with its strategic business orientation, EPBiH will follow the further development trend and apply basic technical elements of the smart grid concept, in order to fully comply with the requirements of modern electricity distribution activity.

\section{ACKNOWLEDGMENT}

The study is selected from International Symposium on Sustainable Development, ISSD 2013.

\section{REFERENCES}

[1] L. Oksanen L. "Distribution system operator as an enabler of the electricity market - Connecting small-scale production and demand response", MSc thesis, Tampere University of Techonology, Finland, 2011.

[2] M. Vuksanić T. Marijanić "Implementation of smart grids concept in Croatian power distribution system regarding European practice“, HRO CIRED, 3.(9.) Session (in Croatian), 2012.

[3] ERGEG, Regulation for Smart Grids, 2011

[4] M. J. N van Werven., M. J. J. Scheepers "The changing role of distribution system operators in liberalised and decentralising electricity markets, DISPOWER report, ECN-C--05-058., 2011.

[5] M. Bošković, T. Cerovečki, Z. Lipošćak Z. "Adaptation of distribution system operator to operation under open electricity market conditions, HRO CIRED, 2.(8.) Session (in Croatian)”, 2010.
[6] Last Accessed on 22.02.2013. About power sector in B\&H www.derk.ba; www.nosbih.ba; www.ferk.ba; www.reers.ba

[7] European Commission, "Communication from the Commission to the European Parliament, the council, the european economic and social committee and the committee of the regions, "Smart Grids: from innovation to deployment, COM 202 final, Brussels, 2011.

[8] T. Jakaša, Dž. Drobić, "Advanced power systems - an overview of European projects", 20. International Symposium EIS 2011, Šibenik, Croatia, 2011.

[9] Internal documentation of Elektroprivreda BiH Sarajevo

[10] FERK, General Conditions for Electricity Supply, 2008.

[11] KfW Study report, "SCADA/DMS and Related Telecommunication Facilities, Distribution Level”, 2008.

\section{BIOGRAPHIES}

Elvisa Bećirović received B.Eng. and M.Sc. degree in electrical engineering from the Faculty of Electrical Engineering, University of Sarajevo and University of Tuzla, respectively. Currently she is a Ph.D. candidate at the Faculty of Electrical Engineering, University of Zagreb. She works at the Department for Strategic Development in EPC Elektroprivreda B\&H.

Mustafa Musić received Ph.D. degree in electrical engineering from the Faculty of Electrical Engineering, University of Sarajevo in 2005. He is a Head of Department for Strategic Development in EPC Elektroprivreda B\&H, and also an assistant professor in Faculty of Electrical Engineering, University of Sarajevo.

Nedžad Hasanspahić has B.Sc. degree in electrical engineering from the Faculty of Electrical Engineering, University of Sarajevo. He is a M.Sc. student with work in the field of smart grid implementation in electricity distribution.

Samir Avdaković received Ph.D. degree in electrical engineering from the Faculty of Electrical Engineering, University of Tuzla in 2012. He works at the Department for Strategic Development in EPC Elektroprivreda B\&H. His research interests are: power system analysis, power system dynamics and stability, WAMPCS and signal processing. 